\title{
PEMETAAN USAHA MIKRO KECIL MENENGAH (UMKM) PADA MASA PANDEMI COVID-19 MENGGUNAKAN ANALISIS MEDIA SOSIAL DALAM UPAYA PENINGKATAN PENDAPATAN
}

\author{
Diah Chaerani ${ }^{1}$, Melda Noereast Talytha ${ }^{2}$, Tomy Perdana ${ }^{3}$, \\ Endang Rusyaman ${ }^{1}$ dan Nurul Gusriani ${ }^{1}$ \\ ${ }^{1}$ Departemen Matematika, FMIPA, Universitas Padjadjaran \\ ${ }^{2}$ Jurusan Kedokteran Gigi Fakultas Kedokteran Gigi, Universitas Padjadjaran \\ ${ }^{3}$ Departemen Sosial Ekonomi Fakultas Pertanian, Universitas Padjadjaran \\ E-mail: d.chaerani@unpad.ac.id, melda17002@mail.unpad.ac.id, tomy.perdana@unpad.ac.id, \\ rusyaman@unpad.ac.id, nurul.gusriani@unpad.ac.id
}

\begin{abstract}
ABSTRAK. Pandemi Covid-19 berdampak besar bagi banyak sektor. Kebijakan pemerintah terkait pandemi telah menghambat aktivitas sehari-hari hingga aktivitas jual beli yang dilakukan oleh usaha mikro, kecil dan menengah (UMKM). Peran UMKM sangatlah penting melihat krisis ekonomi yang akan datang diakibatkan pandemi ini. Maka diperlukan kontribusi langsung dari pemerintah serta masyarakat dalam membangun UMKM. Pendataan dan pemetaan kondisi UMKM pada masa Pandemi Covid-19 melalui analisis media sosial dalam rangka studi peningkatan pendapatan merupakan salah satu solusi permasalahan ini. Dalam makalah ini, disajikan hasil penelitian yang bertujuan untuk melihat bagaimana kondisi serta kendala yang dirasakan UMKM sehingga nantinya dapat dibuat program perencanaan untuk menanggulangi masalah tersebut. Dengan menggunakan teori Analisis Sosial Media, pengambilan data dilakukan melalui kuesioner online yang disebarkan ke publik melalui media sosial. Kuesioner berisikan profil dan kondisi UMKM terkini. Metode penelitian yang digunakan adalah kualitatif dengan analisis deskriptif. Hasil yang didapatkan $39,5 \%$ subjek penelitian pelaku usaha mengalami penurunan penjualan produk, $34,9 \%$ mengalami penjualan meningkat, dan sisanya $25,6 \%$ tidak mengalami perubahan penjualan. Terjadinya persaingan yang ketat di wilayah usahanya disetujui sebanyak $74,4 \%$ responden. Analisis social media diperlukan untuk meningkatkan pendapatan dalam hal peningkatan penggunaan media sosial untuk media promosi dan juga transaksi yang diarahkan menggunakan pemodelan matematika dalam implemetasinya. Sehingga dalam masa pandemi ini, UMKM dapat berupaya untuk tetap memiliki pendapatan meningkat. Sosialisasi dan implementasi program dilaksanakan melalui webinar.
\end{abstract}

Kata Kunci: Pemetaan; Usaha Mikro Kecil dan Menengah; Analisis Sosial Media, Pandemi Covid-19.

ABSTRACT. The Covid-19 pandemic has a large impact on many sectors. Various attempts have been made by the government, thereby affecting social life and has a negative effect on the micro, small and medium enterprises (MSMEs). The development of MSMEs is important as an economic motor that can boost economic growth and national economic recovery to avoid economic recession. Therefore, the government must encourage the growth of MSMEs empowerment. Collecting and mapping MSMEs condition due to Covid-19 pandemic by social media analysis in order to study of business improvement as the initial solution of this problem. The research studies the current conditions of MSMEs due to pandemic so that this article aims to acces the impact of pandemic on these businesses and provide better strategies to help MSMEs. The data was conducted with an electronic data collection form distributed to the public through social media. The questionnaire comprised of MSMEs profile and condition due to pandemic. Data were analysed using descriptive method. The results show that 39.5 percent of MSMEs experienced a decrease in sales turnover. However, 34.9 percent of MSMEs experienced a positive impact in the form of increase in sales turnover and the remainng did not affected. The result shows 74.4 percent of MSMEs feels the inscreasingly competitive market conditions. Social media analysis is needed to increase income in increasing the use of social media for promotion and also transactions directed using mathematical modeling in its implementation. So that during this pandemic, MSMEs can try to continue to have increased income. Program socialization and implementation is carried out through webinars.

Keywords: Mapping; micro, small and medium enterprises (MSMEs); Social Media Analysis, Covid-19 pandemic.

\section{PENDAHULUAN}

Pandemi Covid-19 memberikan dampak besar di dunia. Menurut Maffioli (2020) tingkat kecepatan dan cakupan penyebaran virus ini melebihi kejadian kasus lainnya. Respon masyarakat dalam menghadapi pandemi ini pun sangat berbeda dan dampak yang dirasakan sangatlah besar. Berdasarkan laporan Organization for Economic Co-operation and Development (OECD) dikatakan bahwa pandemi ini akan memberikan ancaman krisis ekonomi besar berupa penurunan aktivitas produksi, merosotnya tingkat konsumsi dan kepercayaan konsumen, hingga penurunan drastis bursa saham. Khan (2020) menyatakanpadapenelitiannyaterhadapperekonomian China dari 15 artikel dan laporan bahwa terjadinya penurunan angka pertumbuhan perekonomian dari 6 persen menjadi 2 persen pada sebelum terjadinya Covid-19. McKibbin \& Vines (2020) serta McKibbin \& Fernando (2020) menyatakan pada penelitiannya 
bahwa wabah Covid-19 menunjukkan dampak pada ekonomi global secara signifikan. Maijamaa (2020) menyatakan penyebaran Covid-19 tidak hanya akan berdampak bagi negara China saja, tetapi juga akan lebih meluas hingga mendunia dikarenakan peran China dalam sektor ekonomi dunia yang kuat.

Indonesia sebagai negara berkembang juga mengalami dan terkena dampak atas pandemic Covid-19 ini. Merujuka pada Amri (2020), dampak tersebut memberikan efek terhadap berbagai sektor. Hal ini terbukti berdasarkan Berita Resmi Statistik No. 39/05/Th. XXIII, 5 Mei 2020, besaran PDB triwulan I-2020 mengalami penurunan pertumbuhan ekonomi dari 5,07 persen (tahun 2019) menjadi 2,97 persen. Badan Kebijakan Fiskal (BKF) Kementerian Keuangan memperkirakan angka kerugian hingga Rp320 triliun pada Triwulan I-2020 akibat pandemi. Hal ini disebabkan ekonomi nasional merosot sekitar 2,03 persen. Tentunya, jika ini tidak ditangani dengan segera maka akan membawa dampak besar yang mengancam perekonomian Indonesia.

Pemerintah dalam mengatasi pandemi mulai memberlakukan Pembatasan Sosial Berskala Besar (PSBB) atau social distancing sejak awal Maret 2020. Peraturan ini memiliki efek nyata pada masyarakat. Aktivitas sehari-hari menjadi terhambat sehingga masyarakat dituntut untuk melakukan setiap kegiatan darirumah dan digitalisasi dalam setiapkegiatan seharihari seperti Work From Home (WFH) hingga belajar secara daring. Menurut Hadiwardoyo (2020) kebijakan PSBB ini harus dilakukan dengan pertimbangan tepat, benar dan waktu yang sesingkat-singkatnya. Hal ini disebabkan, pembatasan yang berkepanjangan dapat berisiko besar ter-kait kemampuan individu dalam menjalankan kehidupannya. Kebijakan ini memberikan dampak penurunan drastis perekonomian Indonesia akibat berhentinya sektor industri pariwisata dan penurunan manufaktur.

Berdasarkan data Badan Pusat Statistik (BPS) Kementerian Koperasi dan Usaha Kecil Menengah (Kemenkop UKM, 2018), Usaha Mikro, Kecil dan Menengah (UMKM) adalah pelaku utama yang mendominasi perekonomian Indonesia. Hal ini terjadi pada saat krisis ekonomi yang melanda Indonesia tahun 1997-1998. Menurut Sarfiah (2019), UMKM sebagai pahlawan atau penopang perekonomian Indonesia, terlihat dari jumlahnya yang terus meningkat pasca krisis tersebut. Sebanyak 64,2 juta UMKM di Indonesia (99 persen dari total unit usaha) tercatat pada tahun 2018 dan memiliki tenaga kerja sebanyak 116,98 juta orang (97 persen dari total tenaga kerja di sektor ekonomi) Sebanyak 60 persen Produk Domestik Bruto Indonesia berasal dari UMKM. Hal ini menyatakan bahwa UMKM berperan penting dalam menjaga perekonomian dalam negeri.
Merujuk pada Amri (2020), pandemi Covid-19 dapat memberikan ancaman dan juga peluang bagi para pengusaha. Ancaman tersebut sudah terlihat, tidak sedikit UMKM yang mengalami kesulitan. Terlihat dari penurunan omzet hingga tidak ada pemasukan sama sekali dan terpaksa gulung tikar diakibatkan oleh kebijakan PSBB. Oleh karena itu, dalam menanggulangi terjadinya hal yang tidak diinginkan, UMKM harus mampu mengambil peluang lain dalam menghadapi pan-demi ini. UMKM harus mampu bersaing dalam mempertahankan eksistensinya di tengah masalah global ini. Perkembangan dan pertumbuhan UMKM harus ditingkatkan dan diberikan perhatian secara intensif oleh pemerintah.

Kebijakan PSBB mengharuskan mayoritas kegiatan dilakukan di rumah atau Work From Home (WFH). Kondisi ini dapat dijadikan pembelajaran bagi para pemilik bisnis untuk beradaptasi dalam menghadapi pandemi. Bagi UMKM hal ini penting untuk dihadapi. Salah satunya, penting untuk mengimplementasikan digitalisasi pada setiap kegiatan jual beli dan interaksi lainnya. Kemampuan teknologi dan inovasi serta kreativitas diperlukan dalam membaca peluang yang ada seperti dalam aspek permodalan usaha, strategi manajemen, strategi promosi dan pemasaran, serta strategi finansial. Peran pemerintah juga diperlukan dalam mendorong keberhasilan UMKM dari segi alokasi perizinan hingga pembiayaan atau permodalan begitupun pelatihan tenaga kerja.

Atas dasar kondisi UMKM pada masa pandemic seperti dipaparkan di ata, dalam makalah ini disajikan hasil pengumpulan data dan pemetaan mengenai gambaran profil usaha sehingga dapat dilihat dan dipelajari lebih lanjut aspek-aspek terkait kelayakan usaha pada masa pandemi ini supaya menjadi pertimbangan dalam melakukan upayaupaya untuk memperkuat UMKM. Dalam makalah ini, pemetaan dilakukan dengan menggunakan tahapan proses Analisis Sosial Media. Dalam hal ini dilakukan pengumpulan melalui penyebaran kuesioner, penentuan lokasi data, pembatasan kata kunci, dan melakukan analisis interpretasi hasil. Data luaran kuesioner diolah dengan menggunakan metode kualitatif. Berdasarkan data yang diperoleh diarahkan upaya peningkatan pendapatan dengan melakukan sosialisasi pentingnya penggunaan sosial media dalam rangka peningkatan pendapatan melalui kegiatan Webinar Pengabdian Pada Masyarakat yang terintegrasi dengan kegiatan KKN (Kuliah Kerja Nyata) secara virtual.

Pada subbab selanjutnya dibahas mengenai analisis situasi UMKM pada masa Pandemi Covid-19 dan metode analisis Sosial Media yang digunakan dalam hal pengolahan data yang diperoleh untuk memetakan kondisi UMKM. 


\section{Analisis Situasi UMKM pada masa Pandemi Covid-19}

Penelitian Awali (2020) mengenai upaya keberlangsungan UMKM dengan pemanfaatan electronic marketing (e-marketing) yang sesuai prosedur telah memberikan dampak positif di tengah pandemi Covid-19. Menurutnya, para pengusaha UMKM tetap dapat melakukan kegiatan produksi dan distribusi barang ke konsumen dan tetap mematuhi aturan social distancing dimana penerapan e-marketing melalui marketplace online sangatlah membantu. Oleh karena itu, hal ini akan berdampak dalam mempertahankan nilai ekonomi.

Pemerintah juga memberikan upaya dalam membantu UMKM melewati pandemi Covid-19 ini. Salah satunya dengan mengurangi tarif pajak selama enam bulan, sejak April 2020 hingga September 20020. Diberikan pula program bantuan pemerintah, seperti Kartu Prakerja dan Keluarga Harapan. Bantuan berupa relaksasi dan restrukturisasi pembayaran pinjaman bagi pelaku UMKM dan koperasi oleh Kementerian Koperasi.

Sebagai studi literatur dalam kajian UMKM pada masa Pandemi Covid-19 ini, menurut Hardilawati (2020) dibutuhkan strategi bertahan bagi UMKM. Strategi tersebut meliputi melakukan kegiatan jualbeli secara online, melakukan promosi dan pemasaran secara digital, melakukan peningkatan kualitas produk dan menambah layanan operasional serta mengoptimalkan interaksi dengan konsumen. Oleh karena itu diperlukan kondisi atau gambaran terkait profil usaha dilihat dari aspek promosi, finansial, manajemen dan lingkungan untuk mengoptimalkan perbaikan UMKM dalam menghadapi pandemi. Selain itu terdapat Pakpahan yang membahas covid-19 dan implikasi bagi UMKM. Kemudian Shofiana (2020) yang membahas implementasi program afiliasi berbasis virtual team dalam umkm sebagai upaya peningkatan perekonomian pada masa pandemi covid-19 serta Taufik (2020) yang membahas dampak pandemi covid 19 terhadap bisnis dan eksistensi platform online. Kajian mengenai ketahanan pangan UMKM Jawa Timur pada masa pandemic covid-19 dibahas oleh Soetjipto, N (2020).

\section{Analisis Media Sosial}

Menurut (Sponder dan Khan, 2018), Analisis Media Sosial adalah proses mengumpulkan dan menganalisis data darijejaring sosialsepertiFacebook, Instagram, dan Twitter. Ini biasanya digunakan oleh pemasar untuk melacak percakapan online tentang produk dan perusahaan. Analitik media sosial juga didefinisikan sebagai, "seni dan ilmu untuk menggali wawasan tersembunyi yang berharga dari sejumlah besar data media sosial semi-terstruktur dan tidak terstruktur untuk memungkinkan pengambilan keputusan yang berwawasan dan berwawasan luas."

Dalam proses menganalisis media sosial terdapat tiga langkah utama, yaitu identifikasi data, analisis data, dan interpretasi informasi. Dalam proses analisis, pertanyaan yang harus dijawab ditentukan untuk dapat memaksimalkan nilai yang diperoleh pada setiap titik selama proses. Pertanyaan penting untuk analisis data adalah "Siapa? Apa? Di mana? Kapan? Mengapa? Bagaimana?" Pertanyaan-pertanyaan ini membantu dalam menentukan sumber data yang tepat untuk dievaluasi, yang dapat memengaruhi jenis analisis yang dapat dilakukan (lihat (Ganis, Matthew; Kohirkar, Avinash (2015)).

Selanjutnya merujuk pada Ganis dkk (2015), proses analisis media sosial dapat dilakukan dengan mengikuti flowchat yang disajikan pada Gambar 1.

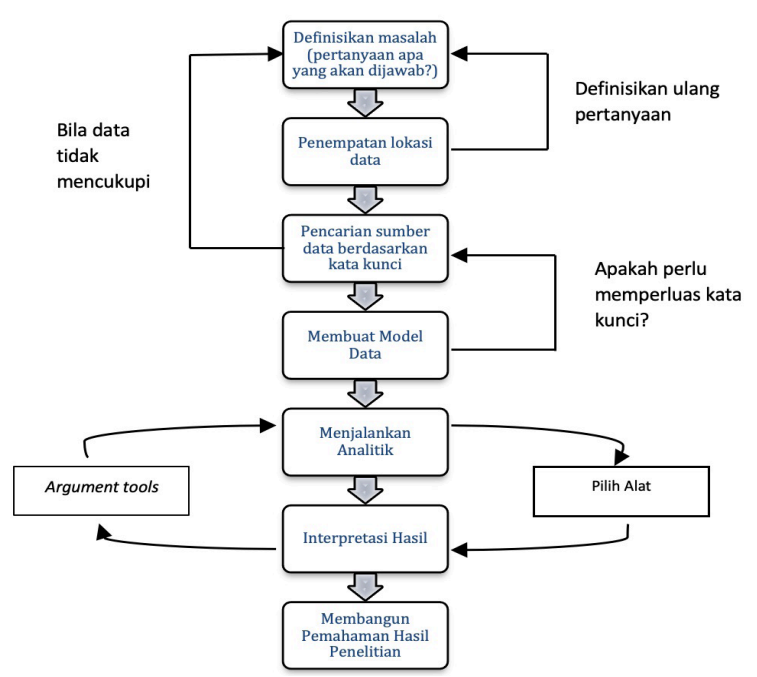

Gambar 1. Proses Analisis Media Sosial (Ganis dkk (2015).

Didefinisikan bahwa analisis data merupakan serangkaian kegiatan yang mengubah data mentah menjadi wawasan. Hal ini berlanjut hingga mengarah pada basis pengetahuan dan nilai bisnis baru. Dengan kata lain, analisis data adalah pengambilan data diseleksi sebagai sebagai input dan ditransformasi menjadi informasi yang bernilai bagi para analis. Data media social dapat digunakan untuk berbagai jenis analisis, termasuk analisis posting, sentimen, pendorong sentimen, geografi, demografi dan lain-lain.

Langkah selanjutanya adalah pengembangan model data. Dalam hal ini dilakukan pengaturan elemen data dan dilakukan standarisasi sehingga dapat dilihat bagaimana elemen data individu berhubungan satu sama lain. Langkah ini penting karena diperlukan untuk dapat diimplementasikan dalah menjalankan program komputer dalam pengolahan data.

\section{METODE}

Merujuk pada pembahasan pada Subbab Tinjauan Pustaka mengenai analisis situasi dan analisis media sosial, dalam makalah ini dilakukan 
pengumpulan data dengan menggunakan metode penelitian kualitatif. Dalam hal ini berarti dilakukan pengumpulan data yang dapat memberikan gambaran kondisi UMKM terkait pandemi covid. Instrumen pengambilan data berupa kuesioner online yang disebarkan ke publik melalui media sosial seperti instagram, whatsapp, dan facebook dengan menempuh tahapan seperti yang digambarkan pada Flowchart Analisis Media Sosial (lihat Gambar 1). Populasi penelitian yaitu para pelaku Usaha Mikro, Kecil dan Menengah (UMKM) di Indonesia.

Pengambilan subjek penelitian dilakukan menggunakan teknik purposive sampling dengan kriteria inklusi dan eksklusi. Kriteria inklusi yaitu usaha aktif beroperasi pada masa pandemi covid dan jabatan responden sebagai pemilik, manajer atau setara dalam usaha. Kriteria eksklusi yaitu pelaku usaha dibawah usia 18 tahun. Berdasarkan kriteria tersebut didapatkan sebanyak 43 responden. Data yang didapat diolah menggunakan analisis deskriptif. Penelitian dilakukan pada bulan Juli 2020.

\section{HASIL DAN PEMBAHASAN}

\section{Hasil Pemetaan UMKM dengan Analisis Sosial Media Demografi Responden}

Penelitian ini berdasarkan data yang telah diperoleh dari responden hasil pengisian kuesioner online pada Tabel 1.

\section{Tabel 1 Demografi Responden}

\begin{tabular}{lcccccc}
\hline \multirow{2}{*}{ Usia } & \multicolumn{2}{c}{ Perempuan } & \multicolumn{2}{c}{ Laki-laki } & \multicolumn{2}{c}{ Total } \\
\cline { 2 - 7 } & jml & $\%$ & jml & $\%$ & jml & $\%$ \\
\hline $18-19$ & 1 & $2.3 \%$ & 0 & $0.0 \%$ & 1 & $2.3 \%$ \\
$\begin{array}{l}\text { Tahun } \\
20-30\end{array}$ & 25 & $58.1 \%$ & 5 & $11.6 \%$ & 31 & $72.1 \%$ \\
Tahun & & & & & & \\
$>30$ Tahun & 9 & $20.9 \%$ & 3 & $7.0 \%$ & 12 & $27.9 \%$ \\
$\quad$ Total & 35 & $81.4 \%$ & 8 & $18.6 \%$ & 43 & $100 \%$ \\
\hline
\end{tabular}

Tabel 1 memperlihatkan bahwa responden berjumlah 43 orang sebagai pemilik usaha. 81 persen responden adalah wanita atau sebanyak 35 orang dan 18 persen adalah laki-laki atau sebanyak 8 orang. Dengan rentang usia yaitu kurang dari 20 tahun sebanyak 1 orang, antara 20 sampai 30 tahun sebanyak 31 orang dan lebih dari 30 tahun sebanyak 12 orang.

Hal ini sejalan dengan hasil survei Asosiasi Penyelenggara Jasa Internet Indonesia (APJJI) pada tahun 2018 yang membuktikan bahwa jika pengambilan data dilakukan secara online, maka kaum milenial sebagai responden terbanyak sehingga data ini mayoritas diisi oleh usia 20 tahun ke atas. Didapatkan juga bahwa perempuan sebagai mayoritas responden pemilik usaha terbanyak dibandingkan laki-laki. Hal ini sejalan dengan data mengenai UMKM oleh Bank Indonesia di tahun
2018 bahwa jumlah pelaku UMKM perempuan di Indonesia mencapai 37 juta atau sekitar lebih dari 60 persen. Hal ini disebabkan karena perempuan secara signifikan lebih memilih untuk memiliki usaha mikro karena adanya kendala pada fleksibilitas waktu dan peluang kerja di perusahaan dibandingkan laki-laki.

\section{Profil UMKM}

Berikut profil usaha diketahui berdasarkan jenis usaha, kurun waktu dan omzet perbulan. Gambar 2 menunjukkan jenis usaha yang dilakukan oleh responden atau subjek penelitian. Sebanyak 51,6 persen subjek penelitian memiliki usaha barang konsumsi berupa makanan dan minuman. Kemudian, 20,93 persen di bidang fashion berupa pakaian, tas, jam tangan serta aksesoris lainnya. Sebanyak 13,95 persen pelaku usaha di bidang jasa berupa jasa antar jemput, laundry, printing, fotocopy dan lainnya.

Pada bidang karya seni berupa buku, desain dan logo sebanyak 9,3 persen dan hanya 2,3 persen pelaku usaha pada bidang pertanian dan produk kesehatan (masker, hand sanitizer, APD, dan alat kesehatan lain). Mayoritas responden memiliki usaha mikro ditunjukkan data (Gambar 3) dimana sebanyak 69,8 persen mendapatkan omzet perbulan di bawah Rp. 25.000.000,00. sebanyak 18,6 persen mendapatkan omzet perbulan antara Rp. 25.000.000,00. - Rp. 200.000.000,00. (usaha kecil), dan sebanyak 11,6 persen mendapatkan omzet perbulan di atas $\mathrm{Rp}$. 200.000.000,00. (usaha menengah).

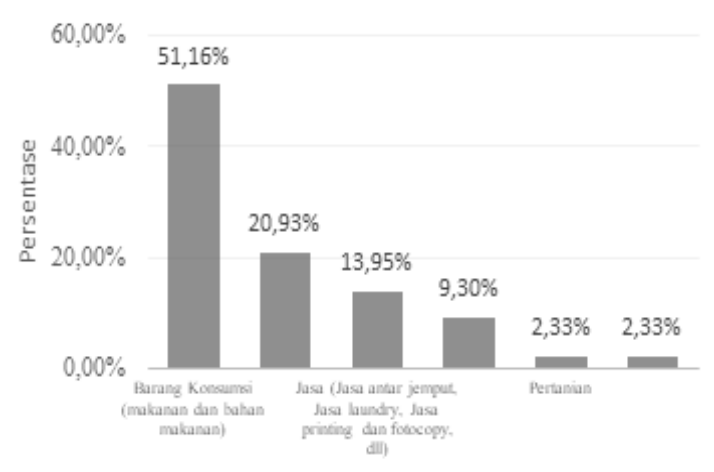

Gambar 2. Jenis Usaha

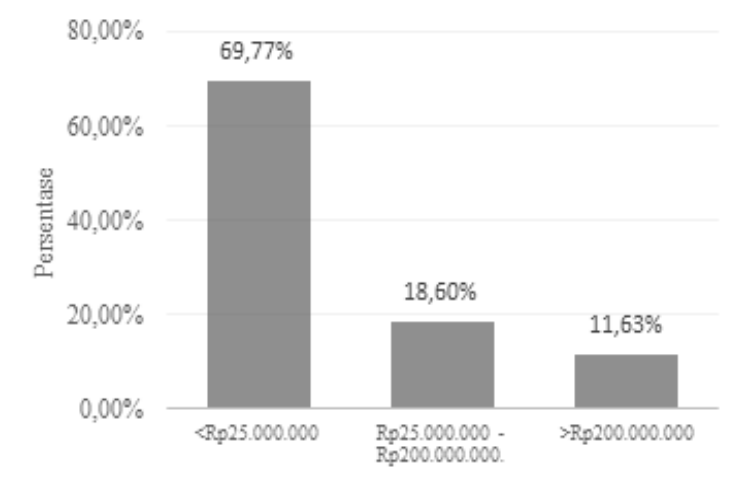

Gambar 3. Omset Perbulan 
Gambar 4 dapat diketahui sebanyak 37,21 persen responden sudah menekuni usahanya kurang dari 1 tahun khususnya. Sebanyak 44,19 persen menekuni usahanya antara 1-5 tahun terakhir ini disebabkan oleh perkembangan era digital dan pertumbuhan ekonomi yang semakin meningkat. Kemudian 18,6 persen subjek penelitian sudah menekuni usahanya lebih dari 5 tahun.

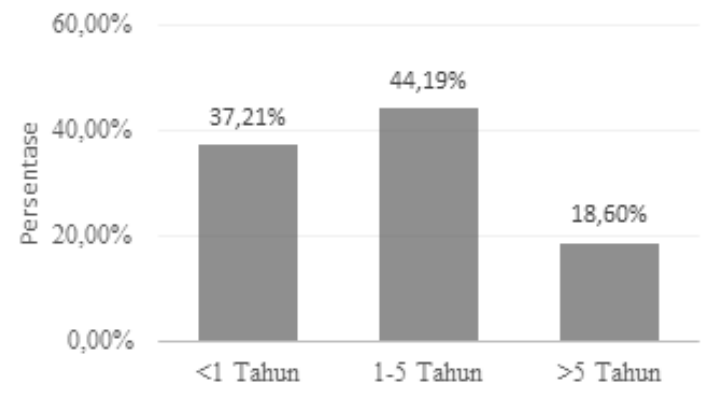

\section{Gambar 4. Kurun Waktu Usaha Dijalani}

Pada data yang dilansir oleh Badan Pusat Statistik(BPS) menunjukkan bahwa laju pertumbuhan Produk Domestik Bruto (PDB) pada sektor kuliner dari tahun 2017 hingga 2019 berkisar antara $7.78 \%$ - 9.23\% dimana dalam kurun waktu 3 tahun terakhir telah mengalami penurunan namun tidak signifikan. Hal tersebut membuktikan bahwa sektor kuliner menjadi salah satu sektor yang mendominasi UMKM. Bersumber pada data yang dikeluarkan oleh Kementerian Koperasi dan Usaha Kecil Menengah (Kemenkop Ukm) menyatakan bahwa usaha mikro adalah usaha dominan yang ada di Indonesia. Pada tahun 2018, usaha mikro menguasai 98.68 persen dari total jenis usaha mikro, usaha kecil, usaha menengah, dan usaha besar. Dengan persentase kontribusi terhadap PDB sebanyak 34,12 persen untuk usaha mikro. Hal ini perlu dijadikan dasar pertimbangan demi perkembangan UMKM dalam menjaga perekonomian Indonesia.

Berdasarkan penelitian ini didapatkan mayoritas memiliki pendapatan perbulan kurang dari $25 \mathrm{juta}$, hal ini mungkin disebabkan responden terbanyak adalah pemilik bisnis yang baru memulai usahanya sekitar 5 tahun terakhir. Menurut penelitian Nainggolan (2016) didapatkan juga data bahwa ada pengaruh lama usaha dengan tingkat pendapatannya karena seorang pelaku usaha yang sudah lama tersebut dapat menambah efisiensi dan mampu menekan biaya produksi lebih kecil daripada hasil penjualan. Hal ini didasarkan pada pengalaman dan pengetahuannya. Keadaan ini perlu menjadi perhatian agar UMKM tetap berusaha dalam menjaga usahanya agar terus berkembang. Namun, jika sudah lama menekuni suatu usaha tertentu dan tidak ada peningkatan yang terlihat maka perlu dipelajari kembali terkait manajemen usaha serta perilaku target konsumen.
Kondisi dan Upaya UMKM pada Masa Pandemi

Kondisi UMKM pada masa pandemi dalam penelitian ini diketahui sebagai berikut.

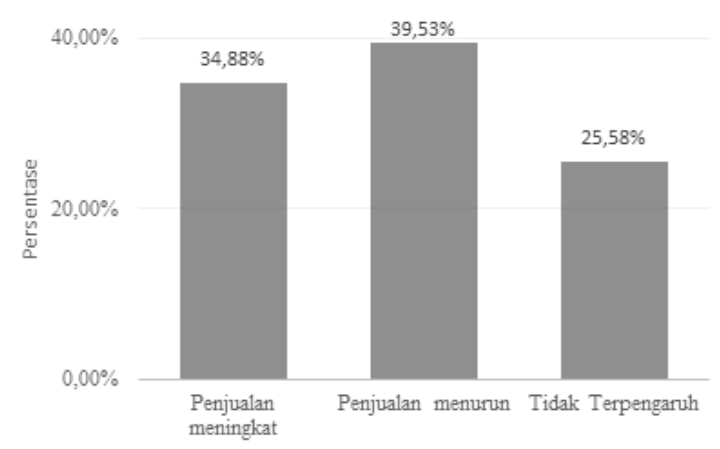

\section{Gambar 5. Kondisi Penjualan Usaha}

Pada Gambar 5 menggambarkan kondisi pengelola pada masa pandemi dan setelah diberlakukannya kebijakan PSBB yaitu, sebanyak 39,53 persen responden mengalami penurunan penjualan. Adapun sebanyak 34,88 persen mengatakan bahwa bisnis mereka mengalami kenaikan penjualan dan sisanya sebanyak 25,58 persen tidak terdampak oleh pandemi Covid-19. Data ini terlihat korelasinya dengan jenis usaha yang dimiliki subjek penelitian dimana dapat diasumsikan bahwa beberapa usaha mengalami penurunan penjualan dan beberapa usaha justru mengalami lonjakan penjualan.

Hal ini ditemukan juga pada penelitian Soetjipto (2020) di Jawa Timur dimana terjadi penurunan omset yang signifikan bahkan beberapa pelaku usaha tidak mampu bertahan. Penurunan tertinggi sebesar $83 \%$ pada usaha perdagangan pakaian dan alat musik. Namun pada penelitian ini rasio perbandingan antara penurunan dan peningkatan penjualan tidak signifikan. Hal ini disebabkan oleh subjek penelitian sebagai pemilik usaha kuliner lah yang paling banyak dan lebih sedikit di bidang pakaian.

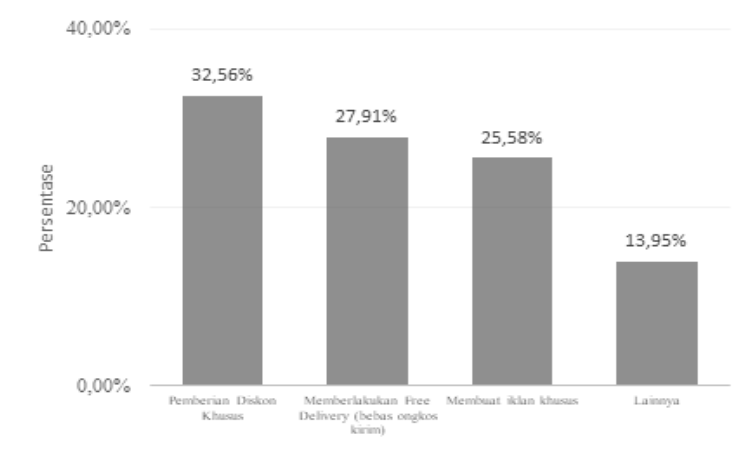

\section{Gambar 6. Upaya UMKM dalam Menghadapi Covid-19}

Berkenaan dengan situasi yang ada, pada Gambar 6 dapat diketahui bagaimana tindakan yang telah dilakukan UMKM demi keberlangsungan usahanya. Beberapa tindakan dalam aspek promosi dan pemasaran yaitu, sebanyak 32,56 persen responden memberikan diskon khusus produk mereka kepada para konsumen dan sebanyak 27,91 
persen juga memilih untuk memberlakukan free delivery (bebas ongkos kirim) kepada para konsumen. Kemudian 25,58 persen pelaku usaha memberikan pembuatan iklan khusus dalam mempromosikan produknya serta 13,95 persen melakukan hal lain.

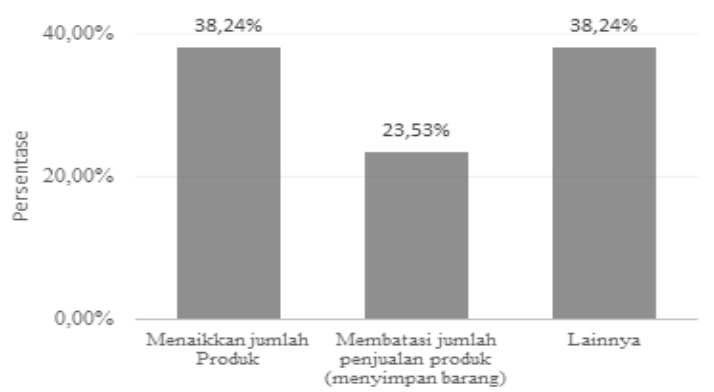

Gambar 7. Persiapan UMKM terhadap Gejala Panic Buying

Gambar 7 memberikan informasi mengenai tindakan atau persiapan khusus apa yang telah dilakukan UMKM dalam menghadapi gejala panic buying. Sebanyak 38,24 persen responden berusaha untuk meningkatkan jumlah produk mereka. Selain itu, para pelaku bisnis sebanyak. Di samping itu, 23,53 persen pelaku usaha mengupayakan membatasi jumlah penjualan produknya dengan menyimpan beberapa barang dan memperkecil jumlah produksi dan sebanyak 38,24 persen memilih hal lain. Hal ini perlu diperhatikan agar kedepannya UMKM dapat memberikan inovasi serta kreasi sebagai upaya dalam meningkatkan pendapatan usahanya.

Dunia sedang mengalami krisis ekonomi yang masif dan tidak bisa dihindari, namun banyak upaya yangdilakukan para pemilikusaha, khususnyaUMKM untuk mempertahankan usahanya. Maka dari itu, UMKM diharapkan untuk mengeluarkan kreativitas dan inovasi lebih sehingga keberlangsungan usahanya dapat terus berjalan. Untuk mendukung hal tersebut, pemerintah dan masyarakat harus berperan aktif dan terjun langsung secara nyata dalam memberikan respon positif untuk mendukung UMKM.

\section{Kendala UMKM}

Berikut data mengenai kendala yang umumnya dihadapi oleh UMKM.

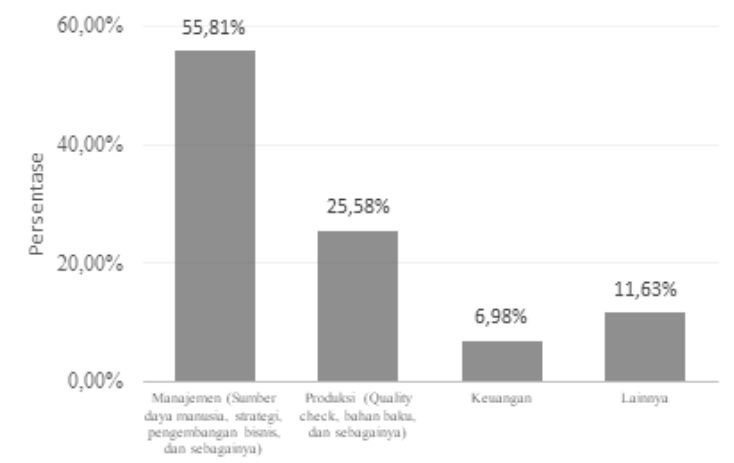

Gambar 8. Kendala yang Dihadapi UMKM
Pada Gambar 8 dicantumkan keempat aspek yang menjadi pilihan. Aspek manajemen sebagai kendala yang umumnya dialami UMKM. Kendala manajemen tersebut berupa manajemen sumber daya manusia, manajemen produksi dan operasi, manajemen strategi, dan sebagainya. Terdapat 55,81 persen yang mengalami kendala pada aspek manajemen, yang kemudian disusul oleh kendala produksi sebanyak 25,59 persen. Kendala produksi meliputi bahan baku, quality control, dan sebagainya. Kendala keuangan dialami sebanyak 6,98 persen dan sisanya mengalami kendala di luar ketiga aspek tersebut. Terkait hal ini maka diperlukan program-program pelatihan guna meningkatkan strategi manajemen dalam mengelola usaha.

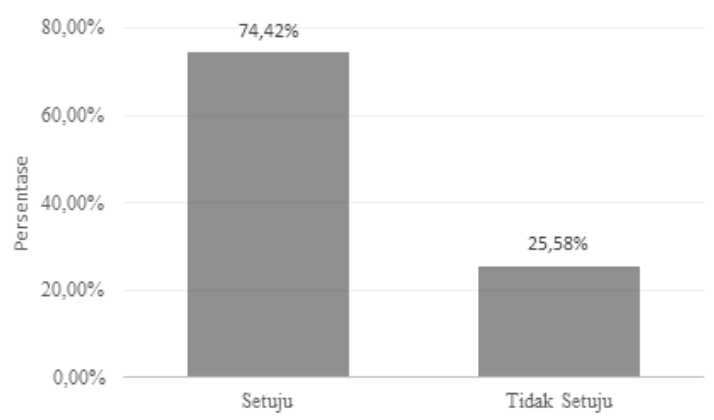

Gambar 9. Persaingan Usaha di Wilayah Ketat

Gambar 9 memperlihatkan bahwa aspek lain mengenai kendala yang dirasakan UMKM adalah adanya persaingan ketat di wilayahnya. Sebanyak 74,42 persen pelaku usaha mengaku setuju akan hal ini. Hal inimenggambarkan bahwa adanya persaingan yang ketat diakibatkan peningkatan jumlah UMKM tiap tahunnya dan era digitalisasi ini. Digitalisasi di berbagai bidang ini dapat menjadi peluang UMKM dalam memanfaatkan capaian konsumen yang lebih luas sehingga bisa meningkatkan pendapatan usahanya. Maka, diperlukan pemahaman dan penggunaan teknologi digital sebagai sarana UMKM dalam mempersiapkan diri memasuki era digitalisasi sehingga nantinya dapat bersaing dengan para pengusaha berskala besar hingga internasional.

\section{Implementasi Program}

Hasil pemetaan data UMKM yang disajikan pada Subbab 4.1 disosialisasikan melalui Webinar yang terintegrasi dengan Kegiatan Pengabdian pada Masyarakat Hibah Internal Unpad serta Kuliah Kerja Nyata Mahasiswa (KKNM) Virtual Unpad (Lihat Gambar 10).

Khalayak sasaran adalah para pemangku kepen-tingan dalam rangka penyuluhan dan sosialisasi pentingnya Ipteks bagi pelaku bisnis, khususnya penyuluhan untuk peralihan dari bisnis konvensional ke bisnis online. Dalam Webinar ini 
narasumber yang diundang tidak hanya akademisi, tapi pelaku UMKM baik dari Sahabat UMKM Jabar maupun dari perusahaan start up pengguna media social, dalam hal ini Locarvest. Selain itu dilakuka workshop pembuatan akun media social untuk unit usaha yang akan melaksanakan bisnis yang memanfaatkan IPTEKS dalam hal ini media social. Kaji dan tindak, evaluasi hasil diharapkan dapat dilihat dalam kurun waktu 3-5 bulan.

Dalam pemaparan dan implementasi program melalui webinar ini dapat diketahui apakah terjadi fenomena panic buying di masyarakat saat terjadi pandemi Covid-19, Menganalisis bisnis online di masa pandemi Covid-19 dari sisi Studi Kelayakan Produksi, dan Pemasaran. Selain itu, manfaat yang diperoleh adalah para pelaku bisnis online diharapkan dapat melakukan pengecekan dan evaluasi ulang mengenai kelayakan bisnis yang mereka miliki. Masyarakat diharapkan dapat memperoleh informasi mengenai dampak Covid-19 bagi UMKM dan pengaruh marketing melalui media sosial untuk dijadikan sebagai bahan pertimbangan bagi masyarakat yang ingin memulai bisnis online.

Upaya peningkatan pendapatan bagi para pelaku UMKM, data yang diperoleh dari pemetaan UMKM dengan menggunakan tahapan Analisis Sosial Media UMKM baik dari sisi studi kelayakan bisnis, produksi maupun marketing.

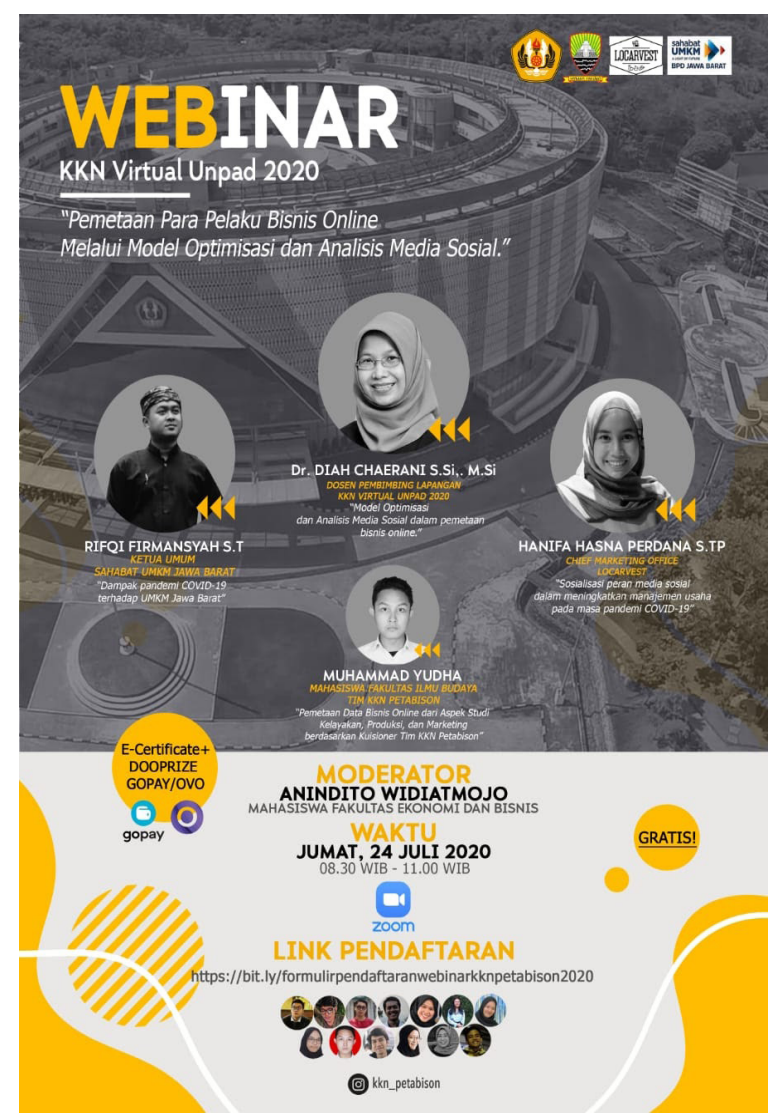

Gambar 10. Poster Webinar Pemetaan Bisnis Online melalui Model Optimisasi dan Analisis Sosial Media

\section{SIMPULAN}

Penelitian ini mengidentifikasi bagaimana kondisi UMKM terkait pandemi Covid-19 dengan menggunakan Analisis Sosial Media. Hasil yang diperoleh setelah dilakukan survei, mayoritas pelaku usaha mendapatkan efek negatif akibat pandemi. Dapat disimpulkan bahwa data yang diperoleh dari penelusuran berbagai medias social dengan kombinasi penyebaran kuesioner menunjukkan bahwa pada masa pandemic terjadi penurunan penjualan dan adanya kendala manajemen serta produksi. Di sisi lain, ditemukan bahwa umumnya untuk para pelaku usaha di bidang kesehatan terjadi peningkatan penjualan. Sebagian besar pelaku usaha merasakan adanya persaingan ketat di wilayahnya sehingga diperlukan inovasi serta strategi baru dalam membangun UMKM ke arah yang lebih baik. Program lanjutan yang direncanakan adalah pendampingan pada pelaku UMKM yang dapat diimplementasikan dalam masa kerja Pengabdian pada Masyarakat Unpad yang terintegrasi dengan Kuliah Kerja Nyata Mahasiswa pada masa yang akan datang.

\section{UCAPAN TERIMA KASIH}

Hasil penelitian ini merupakan bagian dari Hibah Pengabdian Kepada Masyarakat Hibah Internal Universitas Padjadjaran Tahun Anggaran 2020 dengan Nomor Kontrak : 1397/UN6.3.1/PM/2020

\section{DAFTAR PUSTAKA}

Amri, A. (2020). Dampak Covid-19 Terhadap UMKM di Indonesia. Brand Jurnal Ilmiah Manajemen Pemasaran, 2(1), 123-131.

Awali, H. (2020). Urgensi Pemanfaatan E-marketing Pada Keberlangsungan UMKM di Kota Pekalongan Di Tengah Dampak Covid-19. BALANCA: Jurnal Ekonomi dan Bisnis Islam, 2(1), 1-14.

Badan Pusat Statistik. (2008). Pertumbuhan Ekonomi Indonesia Triwulan I-2020 No. 39/05/Th. XXIII. Jakarta: Badan Pusat Statistik.

Ganis, Matthew; Kohirkar, Avinash (2015). Social media Analytics: Techniques and insights for Extracting Business Value Out of Social Media. New York: IBM Press. pp. 40137. ISBN 978-0-13-389256-7

Hadiwardoyo, W. (2020). Kerugian Ekonomi Nasional Akibat Pandemi Covid-19. BASKARA: Journal of Business \& Entrepreneurship, 2(2), 83-92.

Kementerian Koperasi dan Usaha Kecil dan Menengah Republik Indonesia. (2018). Perkembangan 
Data Usaha Mikro, Kecil, Menengah (UMKM) dan Usaha Besar (UB) Tahun 2017-2018.

Hardilawati, L.W. (2020). Strategi Bertahan UMKM di Tengah Pandemi Covid-19. Jurnal Akuntansi dan Ekonomika, 10(1), 89-98.

Maffioli, E. M. (2020). How Is the World Responding to the Novel Coronavirus Disease (COVID-19) Compared with the 2014 West African Ebola Epidemic? The Importance of China as a Player in the Global Economy. The American Journal of Tropical Medicine and Hygiene, 102(5), 924-925.

Maijamaa, B., Nweze, N. O., \& Bagudu, H. D. (2020). Coronavirus Disease (Covid-19), is Global Recession Evitable?. Jurnal Aplikasi Manajemen, Ekonomi dan Bisnis, 4(2), 71-77.

McKibbin, W. J., \& Vines, D. (2020). Global macroeconomic cooperation in response to the COVID-19 pandemic: a roadmap for the G20 and the IMF. Forthcoming in 'The Economics of the COVID-19 Pandemic, 36.

McKibbin, W. J., \& Fernando, R. (2020). The global macroeconomic impacts of COVID-19: Seven scenarios.

Nainggolan, R. (2016). Gender, tingkat pendidikan dan lama usaha sebagai determinan penghasilan
UMKM Kota Surabaya. KINERJA, 20(01), $1-12$.

Pakpahan, A. K. (2020). Covid-19 Dan Implikasi Bagi Usaha Mikro, Kecil, Dan Menengah. Jurnal Ilmiah Hubungan Internasional, 5964.

Sarfiah, S. N., Atmaja, H. E., \& Verawati, D. M. (2019). UMKM Sebagai Pilar Membangun Ekonomi Bangsa. Jurnal REP (Riset Ekonomi Pembangunan), 4(2), 137-146.

Shofiana, A. (2020). Implementasi Program Afiliasi Berbasis Virtual TeamDalamUMKMSebagai Upaya Peningkatan Perekonomian Pada Masa Pandemi Covid-19 (Implementation Of Virtual Team-Based Affiliation Programs In Msmes As Efforts For Increasing The Economy In The Covid-19 Pandemic Period). Available at SSRN 3590822.

Soetjipto, Noer (2020) Ketahanan UMKM Jawa Timur Melintasi Pandemi COVID-19. K-Media, Yogyakarta. ISBN 978-602-451813-4

Taufik, T., \& Ayuningtyas, E. A. (2020). Dampak Pandemi Covid 19 Terhadap Bisnis Dan Eksistensi Platform Online. Jurnal Pengembangan Wiraswasta, 22(01), 21-32. 